\title{
FORESTS AND LUMBERING REFERENCES
}

Prepared by W. M. Gregory,

Normal School, Cleveland, Ohio.

The following list of references upon forests and lumbering has been prepared for the help of students and teachers of commercial and industrial geography, agriculture, and manual training. The list includes the sources that ought to be used when these subjects are well taught, and the star $\left({ }^{*}\right)$ indicates that the book has been used with junior high school students.

1. Adams, Commercial Geography, Chap. 11, map.

2. *ADAMs, El. Commercial Geog., p. 96.

3. *ALIEN, Industrial Studies -United States, p. 253.

4. American Agriculture, Cyclopedia of, Vol. I, p. 11.

5. *American Lumberman, January 15, 1910. Fine pictures.

6. American Lumberman, August 3, 1907, "Story of White Pine."

7. BAIlex, How the Trees Look in Winter.

8. Bowman, Fores Physiography.

9. BLAICH, Three Industrial Nations, p. 214.

10. *BRADISH, Stories from Gardens and Field.

11. Brigham, Commercial Geog., p. 138.

12. Bullock, Timber. Common Commodities of Commerce.

13. *CARPENTER, F. G., How the World Is Sheltered, p. 64-98.

14. Century Magazine, Vol. 66, p. 85, 1903.

15. *Chamberlain, How We Are Sheltered, p. 89-109.

16. Cochrane, Modern Industrial Progress, p. 274-91.

17. Cosmopolitan, "Great Industries of the United States," Vol. 34,437 .

18. Dawson, "Forest Problems," Journal of Geography, February, 1909.

19. *Freeman and Chandler, Com. Products.

20. Gibson, Harwood Record, 1913.

21. HUN'TER, Civic Biology, "Story of Piseidonia."
22. JACKsoN, Sci. and Math., April, 1912.

23. *Journal of Geography, October, 1910, "Lumbering in U. S." 24. *Keller and Bishop, Commercial and Indus. Geog., p. 56.

25. KellogG, Lumber and Its Uses.

26. KeLlogG, Lumber Industry.

27. *LANE, Industries of Today, p. 59 .

28. *McMurRy, Special Method in Geog., p. 73.

29. "McMurry, Type Studies in Geog. of U. S., p. 132.

30. *MCFEe, Gifts of the Forests.

31. *MrLus, Searchlights on Some American Industries, p. 1.

32. Moon AND Brown, Elements of Forestry.

33. *MonRIs, Indus. and Com. Geog., p. 109.

34. *Moone, Industrial History, p. 33.

35. Noxes, Handbook of Wood.

36. Outlook, Vol. 70, p. 18 and 803.

37. *Plommer, Ray and Roy in Canada, p. 59.

38. REDWAY, Com. Geog., p. 23, 132.

39. Review of Reviews, "Lumber as American Industry," November, 1907.

40. Robinson, Commercial Geography, p 23, 132.

41. *Rochenead, Great American Industries, p. 7-36.

42. *Rusmisel, Indus. and Com. Geog. of U. S., p. 136.

43. SALISBURX, ET AL., Elements of Geog., p. 556.

44. Scribner's Magazine, Vol, 13, p. 707, "Pine in Michigan." 
45. Semple, American History and Its Geographic Conditions, p. $153,344$.

46. *Seton, E. T., Foresters Manual.

47. *St. Nicholas, Vol. 25, p. 20, "Story of a Pine Tree."

48. *Smith, J. Russele, Commerce and Industry, p. 182.

49. Smite, J. Russele, Industrial and Commercial Geography, p. 418.

50. Sthvenson, Trees of Commerce. 308 .

51. Towne, Social Problems, p.

52. Trotter, Geography of Commerce, p. 105.
53. VAN HISE, Conservation of Natural Resources.

54. U. S. Census, Vol. X, p. 487.

55. U. S. Forest Service Circular, No. 159.

56. U. S. Forest Service Circular, No. 166 .

57. U. S. Forest Service Circular, No. $1 \% 1$.

58. U. S. Farmers' Bulletin, No. 468 , Forestry in Nature Study.

59. U. S. Dept. of AgriculTURE, Forest Service Map of North America.

60. U. S. Dept. OF AgriculTणRE, Lumber Cut of the United States.

\section{THE GRAPH OF $a x^{2}+b x+c$.}

BY J.L. P. PAtterson,

Chestnut Hill Academy, Chestnut Hill, Pa.

The solution of $a x^{2}+b x+c=0$ gives $x=\frac{-b \pm \sqrt{b^{2}-4 a c}}{2 a}=\frac{-b}{2 a}+\frac{\sqrt{b^{2}-4 a c}}{2 a}=$ $\frac{-b}{2 a} \pm k$, say. It is evident from the latter form that $\frac{-b}{2 a}$ is the axis of the graph and if $\frac{-b}{2 a}$ be substituted for $x$ in the equation $a x^{2}+b x+c=y$, the value of $y$ resulting will be the lowest point of the graph. (If the first term is negative, the value of $y$ will be the highest point of the graph.) The point in which the graph cuts the axis of $\mathrm{X}$ may be found, as usual, by making $x=0$ and the symmetrieal point is at once determined. Thus we know the axis, the lowest (or highest) point and two other points, which will give the graph roughly by a minute's work. If the graph cuts the axis of $X$ (that is, if there are real roots; not equal), two other points are readily determined by the solution of the equation.

Take for example, $2 x^{2}-5 x+8=0 . \quad x=\frac{-b}{2 a} \pm k=\frac{5}{4} \pm k$.

$\therefore x=\frac{5}{4}$ is the axis and if $\frac{5}{4}$ be substituted for $x$ in $2 x^{2}-5 x+8=y, y=47 / 8$,

the lowest point. Again, if $x=0, y=8$ and the opposite symmetrical 5

point is $\frac{5}{4}$ to the right of the axis. 